\section{Partitioning of Nitrogen and Carbon in Phalaenopsis and Their Progressive Changes with Plant Growth and Development}

\author{
Jen-An Lin and Yao-Chien Alex Chang ${ }^{1}$ \\ Department of Horticulture and Landscape Architecture, National Taiwan \\ University, Taipei 10617, Taiwan
}

Additional index words. tissue analysis, $\mathrm{C} / \mathrm{N}$ ratio, plant nutrition, maturity index, flowering, orchid

\begin{abstract}
Phalaenopsis (Phalaenopsis spp.) is the most important indoor potted plant worldwide. Tissue analysis is very important for managing fertilization practices but the effects of sampling position and plant maturity must be considered. However, there has been little research on the distribution of tissue carbon $(C)$ and nitrogen $(N)$ among leaves and changes of tissue $C$ and $N$ composition during various developmental stages in phalaenopsis. In this study, we thus determined the effects of leaf age, plant maturity, and cultivars on $\mathbf{C}$ and $\mathbf{N}$ partitioning in phalaenopsis. Overall, $\mathbf{C}$ concentration was more uniform and was less affected by the abovementioned factors investigated, whereas $N$ concentration significantly decreased as leaves aged or as plants matured. In $P$. Sogo Yukidian ' $V 3$ ', new expanding leaf had the highest $N$ concentration of $2.72 \%$ of dry weight (DW) and seventh mature leaf had the lowest value of $1.48 \% \mathrm{DW}$. Results also indicate that $\mathbf{N}$ was not evenly distributed within a leaf, whereas $\mathbf{N}$ concentration gradually decreased from the leaf tip to the leaf base. The middle section of the second mature leaf is an appropriate tissue for sampling to obtain the representative $\mathrm{N}$ and $\mathrm{C}$ concentrations in phalaenopsis. As for the changes in $\mathrm{C}$ and $\mathrm{N}$ composition through five developmental stages, two cultivars were compared, including the large, white-flowered $P$. Sogo Yukidian 'V3' and the small, purple-flowered $P$. Sogo Lotte 'F2510'. As the largeflowered ' $V 3$ ' grew from deflasked plantlet to fully matured plant (18 months after deflasking) in a 10.5- $\mathrm{cm}$ pot, whole-plant $\mathrm{N}$ concentration decreased from $4.63 \% \mathrm{DW}$ to $1.67 \% \mathrm{DW}$ and $\mathrm{C} / \mathrm{N}$ thus increased from 9.1 to 26.1. Despite the large difference in plant size, the small-flowered 'F2510' had a similar trend and values during vegetative growth stages. However, the two cultivars had different trends during reproductive stages. Tissue $\mathbf{N}$ concentration and $\mathrm{C} / \mathrm{N}$ did not further change as mature large-flowered ' $\mathrm{V} 3$ ' plants were forced to flower. By contrast, tissue $\mathbf{N}$ concentration in small-flowered 'F2510' further decreased and $\mathbf{C} / \mathrm{N}$ thus further increased, which was due to its small stored $\mathrm{N}$ pool. Major $\mathrm{N}$ sink organ shifted from roots to inflorescences during reproductive growth and the stored $N$ in roots as well as in leaves was then used for flower development.
\end{abstract}

Phalaenopsis (the moth orchid) is currently the most important indoor potted flowering plant worldwide (Royal Flora Holland, 2017; U.S. Department of Agriculture, 2016). Growers normally produce phalaenopsis at high temperatures $\left(>28{ }^{\circ} \mathrm{C}\right)$ to promote vegetative growth (Chen et al., 1994; Yoneda et al., 1991). With sufficient light (Wang, 1995), mature plants can then be forced to flower at lower temperatures (20 to

Received for publication 7 Sept. 2017. Accepted for publication 6 Oct. 2017.

This study is a part of the thesis submitted by Jen-An Lin in partial fulfillment of Master of Science degree requirements. We thank Hadi Susilo for his constructive comments on the article. Financial support was provided by the Agriculture and Food Agency, Council of Agriculture, Taiwan (105AS-9.6.1-FD-Z1).

${ }^{1}$ Corresponding author. E-mail: alexchang@ntu. edu.tw. ORCID ID: 0000-0003-4102-0174. $25^{\circ} \mathrm{C}$ ) (Lee and Lin, 1984; Yoneda et al., 1992). Although flowering of phalaenopsis is mainly controlled by low temperature, mineral nutrition also plays an important role in flowering (Lee and Lin, 1987; Poole and Seeley, 1978; Sheehan, 1961; Tanaka et al., 1988).

Ratio of tissue $\mathrm{C}$ and $\mathrm{N}$ is called $\mathrm{C} / \mathrm{N}$ ratio. In the literature, high tissue $\mathrm{C} / \mathrm{N}$ promotes reproductive growth; low $\mathrm{C} / \mathrm{N}$ increases vegetative growth and may inhibit flowering (Klebs, 1918). In Pharbitis nil, seedlings with high tissue $\mathrm{C} / \mathrm{N}$ were more sensitive to the inductive dark periods, which resulted in a higher flowering rate (Wada and Shinozaki, 1985). In Oncidium Gower Ramsey, there was a positive correlation between tissue $\mathrm{C} / \mathrm{N}$ and flowering quality (Wang, 2011). Tissue analysis can directly reveal plant nutrient status, but sampling position and the effects of plant developmental stages must be considered to appropriately interpret the results. However, there has not been a significant amount of research on the distribution of tissue $\mathrm{C}$ and $\mathrm{N}$ and their partitioning during the development of phalaenopsis. The literature on how $\mathrm{C}$ and $\mathrm{N}$ affect growth and flowering of phalaenopsis is also limited.

The $\mathrm{N}$ concentration of mature leaves in phalaenopsis was between $1.93 \% \mathrm{DW}$ and 2.83\% DW (Poole and Sheehan, 1974). N concentration is affected by the location of leaf, cultivars (Poole and Sheehan, 1974), and $\mathrm{N}$ level in fertilizer (Wang and Konow, 2002). N concentration decreases as leaves became more mature in phalaenopsis (Poole and Sheehan, 1974). Susilo et al. (2013) compared $\mathrm{N}$ concentrations at different leaf locations in Phalaenopsis Sogo Yukidian 'V3' and found that new leaf had the highest $\mathrm{N}$ concentration of $2.31 \%$ and the sixth leaf had the lowest value of $1.16 \%$. Kataoka et al. (2004) took five pairs of leaf discs, where each pair was symmetrically positioned with respect to the midrib, at five different distances from the leaf tip for sugar analysis. The second, third, and fourth leaf disc pairs from the leaf tip had almost the same amount of sugar, but the first and fifth pairs had different values. The literature indicates that $\mathrm{C}$ and $\mathrm{N}$ are not evenly distributed in the leaves of phalaenopsis (Kataoka et al., 2004; Poole and Sheehan, 1974; Susilo et al., 2013). Appropriate sampling position is thus crucial for correctly interpreting the results of tissue analysis.

Many orchids have enlarged stems called pseudobulbs, which can store water, carbohydrate, and minerals (Ng and Hew, 2000). Phalaenopsis does not have pseudobulbs, but its succulent leaves and roots have been proved to have storage function of $\mathrm{N}$ (Susilo et al., 2013). With $90 \%$ reduction in fertilizer during reproductive stage, flowering quality was only slightly reduced compared with the full-fertilization treatment in phalaenopsis and stored $\mathrm{N}$ became the major $\mathrm{N}$ source for inflorescence development (Susilo and Chang, 2014). Susilo et al. (2014) compared $\mathrm{N}$ concentrations of whole plant at five developmental stages in Phalaenopsis Sogo Yukidian 'V3' and found the $\mathrm{N}$ concentrations of young plant, just-matured plant, well-matured plant, plant with flower bud visible, and plant with $2 / 3$ flowers opened were $2.00 \%, 2.35 \%, 2.18 \%, 1.82 \%$, and $1.84 \%$, respectively. Their data implied that a natural change, in the form of decreasing $\mathrm{N}$ concentration during development, might exist among cultivars in Phalaenopsis. By contrast, Lee and Wang (1997) did not find obvious change in tissue $\mathrm{N}$ concentration during 7 months of transition stage (between juvenile and mature stages) of a hybrid whiteflowered phalaenopsis. Lei (2007) used fully mature white-flowered phalaenopsis (Phalaenopsis amabilis) as plant material and found no significant changes in $\mathrm{N}$ concentration during reproductive stages. Whether $\mathrm{N}$ concentration would naturally decrease or not during development among phalaenopsis cultivars needs to be further understood.

This study aimed to reveal the nature of tissue $\mathrm{N}$ and $\mathrm{C}$ in phalaenopsis and their 
progressive changes with plant growth and development; the similarities and differences between standard-type and miniature-type phalaenopsis in those regards were compared. From the data obtained, we hope to acquire important information regarding precise sampling and how to appropriately interpret the results of tissue analysis for phalaenopsis.

\section{Materials and Methods}

Expt. 1. Distribution of $C$ and $N$ in the leaves of phalaenopsis. Experiment 1 was conducted to determine the appropriate sampling position for tissue $\mathrm{C}$ and $\mathrm{N}$ analysis and the effects of leaf age on $\mathrm{C}$ and $\mathrm{N}$ distribution in phalaenopsis. Vegetative, large, whiteflowered phalaenopsis, Phalaenopsis Sogo Yukidian 'V3', were purchased from Oriental Star Orchids Group (Chiayi, Taiwan). Plants were 17 months old after deflasking and sphagnum moss was used as the growing medium. Each plant had seven matured leaves and one new expanding leaf, which was $50 \%$ to $70 \%$ the length of the first matured leaf. After purchase, the plants were allowed to recover in a $30 / 25{ }^{\circ} \mathrm{C}$ (day/night) growth chamber for $2 \mathrm{~d}$ and then sampling was performed. The second mature leaf was equally separated into five parts from the tip to the base by length. New leaf and first, third, fifth, and seventh mature leaves were also harvested for tissue $\mathrm{C}$ and $\mathrm{N}$ analysis (Fig. 1). Fresh weight and DW were recorded. The whole-leaf DW, $\mathrm{N}$ concentration, and $\mathrm{C}$ concentration of the second leaf were calculated from the five sections. A completely randomized design with 10 single-plant replications was used.

Expt. 2. Changes of tissue $C$ and $N$ composition in phalaenopsis during various developmental stages. To determine the effects

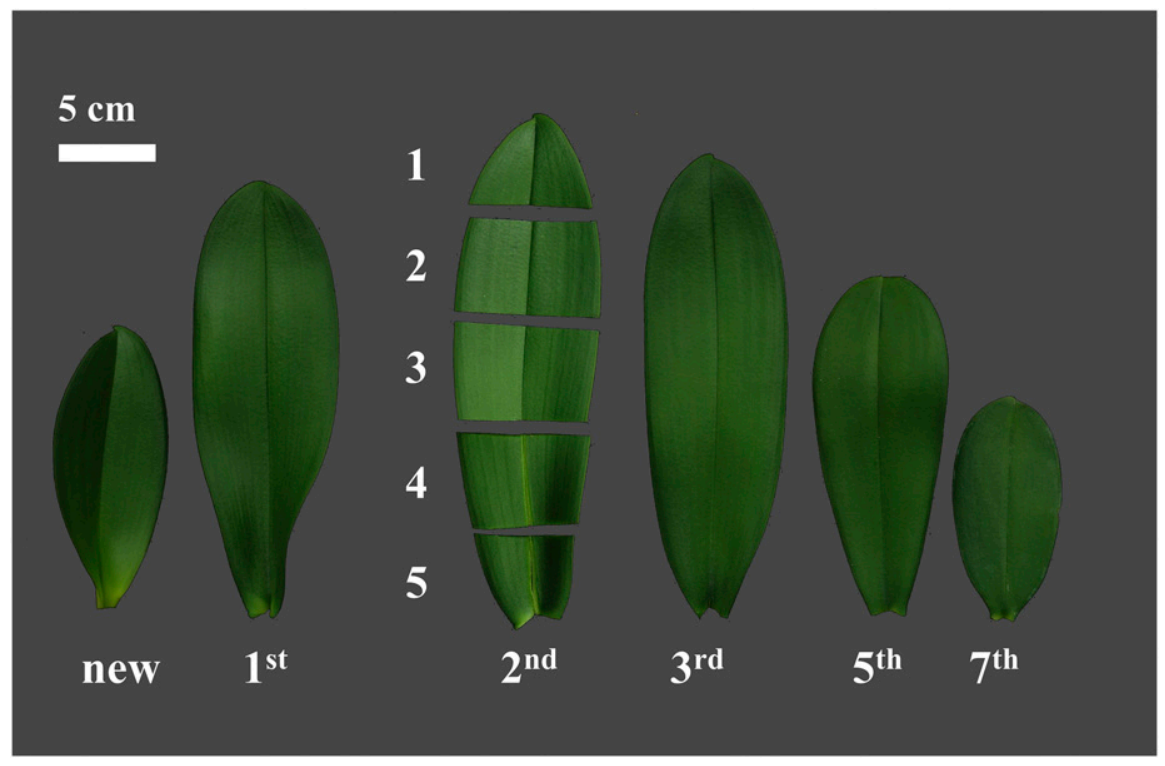

Fig. 1. Definition of leaf locations and leaf positions in Phalaenopsis Sogo Yukidian 'V3' for Expt. 1. Plants were 17 months old after deflasking and with seven mature leaves and one new expanding leaf, which was $50 \%$ to $70 \%$ the length of the first matured leaf. New leaf was the uppermost leaf, while the seventh mature leaf was the oldest leaf. Leaf positions of 1, 2, 3, 4, and 5 of the second mature leaf indicate sections that were equally divided from the tip to the base by length. Bar indicates $5 \mathrm{~cm}$. purple-flowered phalaenopsis $(P$. Sogo Lotte 'F2510') plants were purchased from Sogo Team Co., Ltd. The age of the mature plants was 7 months after deflasking. Plants were forced in a $25 / 20^{\circ} \mathrm{C}$ phytotron with photosynthetic photon flux $(P P F)$ not exceeding 300 $\mu \mathrm{mol} \cdot \mathrm{m}^{-2} \cdot \mathrm{s}^{-1}$ at midday for 3 months and then transferred to a greenhouse with $27.0^{\circ} \mathrm{C}$ average temperature and average $P P F$ of 154 $\mu \mathrm{mol} \cdot \mathrm{m}^{-2} \cdot \mathrm{s}^{-1}$. Fertigation was performed using a water-soluble $20 \mathrm{~N}-8.6 \mathrm{P}-16.6 \mathrm{~K}$ fertilizer (Peters Professional 20-20-20; Everris NA, Dublin, $\mathrm{OH})$ at $50 \mathrm{mg} \cdot \mathrm{L}^{-1} \mathrm{~N}$. Second and third spikes were removed as it reached $0.5 \mathrm{~cm}$ to ensure uniformity of plant materials. Plants were sampled at seven stages. Stage 1: Day 0 , the day forcing started; Stage 2: Day 10; Stage 3: spiking; Stage 4: $40 \mathrm{~d}$ after spiking; Stage 5: bud visible; Stage 6: first flower opened; Stage 7: half flowers opened. Plants were dissected into roots, shoot, and inflorescence (if present) for tissue analysis. Twelve single-plant replications were used in this experiment with a completely randomized design.

Tissue $C$ and $N$ analysis. After drying at $70{ }^{\circ} \mathrm{C}$ to constant weight, samples were ground with high speed blade grinder (RT02; Rong Tsong Precision Technology, Taichung, Taiwan) or tissue grinder ( $\mathrm{SH}-100$; Kurabo Industries Ltd., Osaka, Japan). Between 2.5 and $3.5 \mathrm{mg}$, ground samples were packed into $8 \times 5$-mm tin capsules (Elemental Microanalysis, Okehampton, UK). C and N concentrations were determined by combustion method. A CN Analyzer (Flash EA 1112 Series; Thermo Fisher Scientific, Rodano, Milano, Italy) was used, with combustion and reduction temperatures of 900 and $680{ }^{\circ} \mathrm{C}$, respectively. Atropine $\left(\mathrm{C}_{17} \mathrm{H}_{23} \mathrm{NO}_{3}\right.$, A0132; Sigma, St. Louis, MO) was used as a standard. The content of $\mathrm{C}$ or $\mathrm{N}$ was obtained by multiplying DW by the respective $\mathrm{C}$ or $\mathrm{N}$ concentration.

Statistical analysis. Data were subjected to analysis of variance using completely randomized design. Means separation was performed by the least significance difference test at $P \leq 0.05$. Statistical analysis was completed using Costat (version 6.1; CoHort Software, Monterey, CA).

\section{Results}

Expt. 1. Distribution of $C$ and $N$ in the leaves of phalaenopsis. The $\mathrm{C}$ concentrations of whole leaf in large, white-flowered phalaenopsis 'V3' were between $43.0 \%$ DW and $43.8 \%$ DW. Although there were statistical differences in $\mathrm{C}$ concentrations among leaves at various locations, the difference in values was relatively small and without an obvious increasing or decreasing trend (Table 1). N was not evenly distributed among leaves; $\mathrm{N}$ concentration decreased as leaves became more mature (from top to bottom). New leaf had the highest value of $2.72 \%$, and the first mature leaf had the second highest value of $2.14 \%$. The $\mathrm{N}$ concentrations of the second to the fifth mature leaves were between $1.86 \%$ and $1.92 \%$, which were relatively stable and 
Table 1. Changes of dry weight (DW) and carbon (C) and nitrogen (N) concentrations and contents as well as C/N ratio in Phalaenopsis Sogo Yukidian 'V3' at different leaf locations and positions of the second mature leaf.

\begin{tabular}{|c|c|c|c|c|c|c|c|}
\hline \multicolumn{2}{|c|}{$\overline{\text { Leaf location (whole leaf) }}$} & Dry wt $(\mathrm{g})$ & C concn $(\% \mathrm{DW})$ & $\mathrm{N}$ concn $(\% \mathrm{DW})$ & $\mathrm{C} / \mathrm{N}$ ratio & C content (mg) & $\overline{\mathrm{N} \text { content }(\mathrm{mg})}$ \\
\hline \multicolumn{2}{|c|}{ First mature leaf } & $1.56 \mathrm{a}$ & $43.1 \mathrm{c}$ & $2.14 \mathrm{~b}$ & $20.1 \mathrm{c}$ & $670 \mathrm{a}$ & $33.3 \mathrm{a}$ \\
\hline \multicolumn{2}{|c|}{ Second mature leaf } & $1.50 \mathrm{a}$ & $43.6 \mathrm{~b}$ & $1.92 \mathrm{c}$ & $22.7 \mathrm{~b}$ & $651 \mathrm{a}$ & $28.8 \mathrm{~b}$ \\
\hline \multicolumn{2}{|c|}{ Fifth mature leaf } & $0.83 \mathrm{c}$ & $43.5 \mathrm{ab}$ & $1.90 \mathrm{c}$ & $23.2 \mathrm{~b}$ & $362 \mathrm{c}$ & $15.7 \mathrm{~d}$ \\
\hline \multicolumn{2}{|c|}{ Seventh mature leaf } & $0.34 \mathrm{e}$ & $43.2 \mathrm{c}$ & $1.48 \mathrm{~d}$ & $29.5 \mathrm{a}$ & $145 \mathrm{e}$ & $5.0 \mathrm{e}$ \\
\hline \multicolumn{2}{|c|}{ Significance $\mathrm{e}^{\mathrm{y}}$} & $* * *$ & $* * *$ & $* * *$ & $* * *$ & $* * *$ & $* * *$ \\
\hline \multirow{2}{*}{ Tip } & 3 & $0.34 \mathrm{a}$ & $43.5 \mathrm{~b}$ & $1.96 \mathrm{~b}$ & $22.3 \mathrm{c}$ & $149.6 \mathrm{a}$ & $6.7 \mathrm{a}$ \\
\hline & 4 & $0.34 \mathrm{a}$ & $43.6 \mathrm{~b}$ & $1.72 \mathrm{c}$ & $25.4 \mathrm{~b}$ & $147.3 \mathrm{a}$ & $5.8 \mathrm{~b}$ \\
\hline Base & 5 & $0.33 \mathrm{ab}$ & $43.4 \mathrm{bc}$ & $1.56 \mathrm{~d}$ & $28.0 \mathrm{a}$ & $143.8 \mathrm{a}$ & $5.2 \mathrm{c}$ \\
\hline Signi & & $* * *$ & *** & $* * *$ & $* * *$ & *** & $* * *$ \\
\hline
\end{tabular}

${ }^{\mathrm{z}}$ Means followed by different letters in columns are significantly different at $P \leq 0.05$ by the least significant difference test; $n=10$.

y*** represents significant at $P \leq 0.001$ by analysis of variance.

with no significant difference. The $\mathrm{N}$ concentration of the seventh mature leaf was $1.48 \%$, which was the lowest value among all leaves (Table 1). As leaves became more mature, $\mathrm{C} / \mathrm{N}$ ratio increased because of the decrease in $\mathrm{N}$ concentration. The seventh mature leaf had the highest $\mathrm{C} / \mathrm{N}$ ratio of 29.5, and the new leaf had the lowest value of 16.1. The $\mathrm{C} / \mathrm{N}$ ratios of second to fifth mature leaves were between 22.7 and 23.2. The first and second mature leaves had higher DW and C content compared with all other leaves. The first mature leaf had the highest $\mathrm{N}$ content of $33.3 \mathrm{mg}$, higher than that of second mature leaf $(28.8 \mathrm{mg})$ and other leaves (Table 1).

In phalaenopsis ' $\mathrm{V} 3$ ', the $\mathrm{C}$ concentrations of five sections in second mature leaf were between $43.2 \%$ and $43.8 \%$, which also had no obvious increasing or decreasing trend (Table 1). N was not evenly distributed among different sections of the second mature leaf, which decreased from the leaf tip to the base. Sections 1 and 2 had the highest $\mathrm{N}$ concentrations of $2.32 \%$ and $2.27 \%$, respectively. The $\mathrm{N}$ concentration of Section 3 was $1.96 \%$, and Section 5 had the lowest value of $1.56 \%$ (Table 1). $\mathrm{C} / \mathrm{N}$ ratio increased from the leaf tip to the base because of a decreasing trend in $\mathrm{N}$ concentration. Section 5 had the highest $\mathrm{C} / \mathrm{N}$ ratio of 28.0 ; Sections 1 and 2 had the lowest values of 19.0 and 19.1 , respectively. $\mathrm{C} / \mathrm{N}$ ratio of Section 3 was 22.3 , which was the closest value to that of whole second mature leaf (22.7). Sections 3, 4, and 5 had the highest DW and $\mathrm{C}$ content among all sections. Sections 2 and 3 had the highest $\mathrm{N}$ contents of 7.0 and $6.7 \mathrm{mg}$, respectively (Table 1 ).

Expt. 2. Changes of tissue $C$ and $N$ composition in phalaenopsis during various developmental stages. For the changes of whole-plant $\mathrm{C}$ concentration in vegetative growth stages, the two cultivars exhibited different trends but the difference is small in value; $\mathrm{C}$ concentrations of the two cultivars were both between $41.4 \%$ and $43.1 \%$ (Fig. 2A and B). On the other hand, both cultivars shared a similar decreasing trend in whole-plant $\mathrm{N}$ concentration as plants became more mature. In the large, white- flowered phalaenopsis ( $P$. Sogo Yukidian 'V3'), $\mathrm{N}$ concentration decreased from $4.63 \%$ to $1.67 \%$ as growth stage progressed from $\mathrm{T}$ to $\mathrm{L}$ (Fig. 2C). In the small, purpleflowered phalaenopsis ( $P$. Sogo Lotte 'F2510'), N concentration decreased from $3.80 \%$ to $2.24 \%$ as growth stage proceeded from $\mathrm{T}$ to $6 \mathrm{M}$ (Fig. 2D). The $\mathrm{C} / \mathrm{N}$ ratio increased as plants became more mature in both cultivars because of the decrease in $\mathrm{N}$ concentration. In the large, white-flowered 'V3', C/N increased from 9.1 to 26.1 as growth stage progressed from $\mathrm{T}$ to $\mathrm{L}$ (Fig. 2E). In the small, purple-flowered 'F2510', C/N ratio increased from 11.3 to 18.6 as growth stage proceeded from $\mathrm{T}$ to $6 \mathrm{M}$ (Fig. 2F). The changes of $\mathrm{C}$ concentration, $\mathrm{N}$ concentration, and $\mathrm{C} / \mathrm{N}$ ratio of respective organs, i.e., shoot and roots, were similar to those of whole plant (data not shown).

During reproductive stages (from $\mathrm{L}$ to $\mathrm{F}$ for 'V3' and from $6 \mathrm{M}$ to $\mathrm{F}$ for ' $\mathrm{F} 2510$ '), the two cultivars had different trends in $\mathrm{C}$ concentration, $\mathrm{N}$ concentration, and $\mathrm{C} / \mathrm{N}$ ratio. In the large, white-flowered ' $\mathrm{V} 3$ ', $\mathrm{C}$ concentration of shoot decreased from $43.6 \%$ to $41.8 \%$ and that of roots decreased from $42.4 \%$ to $40.8 \%$ (Table 2). However, flowering did not further affect $\mathrm{N}$ concentration and $\mathrm{C} / \mathrm{N}$ ratio. In the small, purple-flowered 'F2510', $\mathrm{C}$ concentration of shoot increased from $41.0 \%$ to $42.7 \%$ and that of roots increased from $42.5 \%$ to $43.3 \%$ (Table 3 ). N concentration of shoot decreased from $1.98 \%$ to $1.52 \%$ and that of roots decreased from $2.90 \%$ to $1.71 \%$ (Table 3). $\mathrm{C} / \mathrm{N}$ ratio of shoot increased from 20.8 to 28.1 and that of roots increased from 14.9 to 26.5 (Table 3). C concentrations of inflorescences were higher than those of shoot and roots in both cultivars. $\mathrm{N}$ concentration of inflorescence was lower than those of shoot and roots (at the stage of half flowers opened) in large, white-flowered 'V3', but in contrast, higher $\mathrm{N}$ concentration was found in the inflorescence of small, purple-flowered 'F2510' compared with those found in its shoot and roots (Tables 2 and 3 ).

Expt. 3. Changes of tissue $C$ and $N$ composition in phalaenopsis during reproductive stages. Small, purple-flowered 'F2510' spiked at $22 \mathrm{~d}$ after forcing; first flower bud was visible at $76 \mathrm{~d}$, and half flowers opened at $115 \mathrm{~d}$ after forcing. Total flower number was 10.5 (data not shown). During the reproductive stage (from forcing to half flowers anthesis), total leaf number only slightly increased from 7.0 to 7.7 and no significant change in the length of the first mature leaf was found (data not shown).

From forcing (Stage 1; Day 0) to half flowers opened (Stage 7; Day 115), DW of whole plant increased from 1.16 to $2.13 \mathrm{~g}, \mathrm{~N}$ content increased from 21.7 to $29.5 \mathrm{mg}$, and C content increased from 507.5 to $974.6 \mathrm{mg}$ (Table 4). These data indicate that the plant was actively assimilating during the forcing period for the initiation and development of inflorescences. Because the rate of increment for DW was higher than that of $\mathrm{N}, \mathrm{N}$ concentration decreased from $1.88 \%$ to $1.39 \%$. C concentration increased from $43.8 \%$ to $45.8 \%$; due to the decrease in $\mathrm{N}$ concentration, $\mathrm{C} / \mathrm{N}$ ratio increased from 23.0 to 33.0 (Table 4).

During spike initiation (Stages 1 to 3), DW gain rates of shoot and roots were 5.15 and $6.21 \mathrm{mg} \cdot \mathrm{d}^{-1}$, respectively (Table 5). It is worth noting that during spike elongation period (Stages 3 to 5), DW gain rates of shoot and roots decreased to 2.32 and $2.20 \mathrm{mg} \cdot \mathrm{d}^{-1}$, respectively. Inflorescence had the highest DW gain rate of $4.29 \mathrm{mg} \cdot \mathrm{d}^{-1}$ during spike elongation, which further increased to $11.01 \mathrm{mg} \cdot \mathrm{d}^{-1}$ during flower development (Stages 5 to 7 ). Shoot and roots had negative gains of DW during flower development, indicating a decrease of DW in vegetative organs (Table 5). The trend of $\mathrm{C}$ gain rate was similar to that of DW gain rate. During spike initiation (Stages 1 to 3), $\mathrm{N}$ gain rates of shoot and roots were 26.9 and $74.3 \mu \mathrm{g} \cdot \mathrm{d}^{-1}$, respectively. Roots accounted for $73.4 \%$ of total $\mathrm{N}$ gain. As spikes elongated (Stages 3 to 5), $\mathrm{N}$ gain rates decreased to $1.9 \mu \mathrm{g} \cdot \mathrm{d}^{-1}$ for shoot and $-7.2 \mu \mathrm{g} \cdot \mathrm{d}^{-}$ for roots (Table 5). Inflorescence had the highest $\mathrm{N}$ gain rate of $61.8 \mu \mathrm{g} \cdot \mathrm{d}^{-1}$ during spike elongation, and it further increased to 151.4 $\mu \mathrm{g} \cdot \mathrm{d}^{-1}$ during flower development (Stages 5 to 7). Shoot and roots had negative gains of $\mathrm{N}$ during flower development, which were -41.0 and $-45.8 \mu \mathrm{g} \cdot \mathrm{d}^{-1}$, respectively (Table 5). 


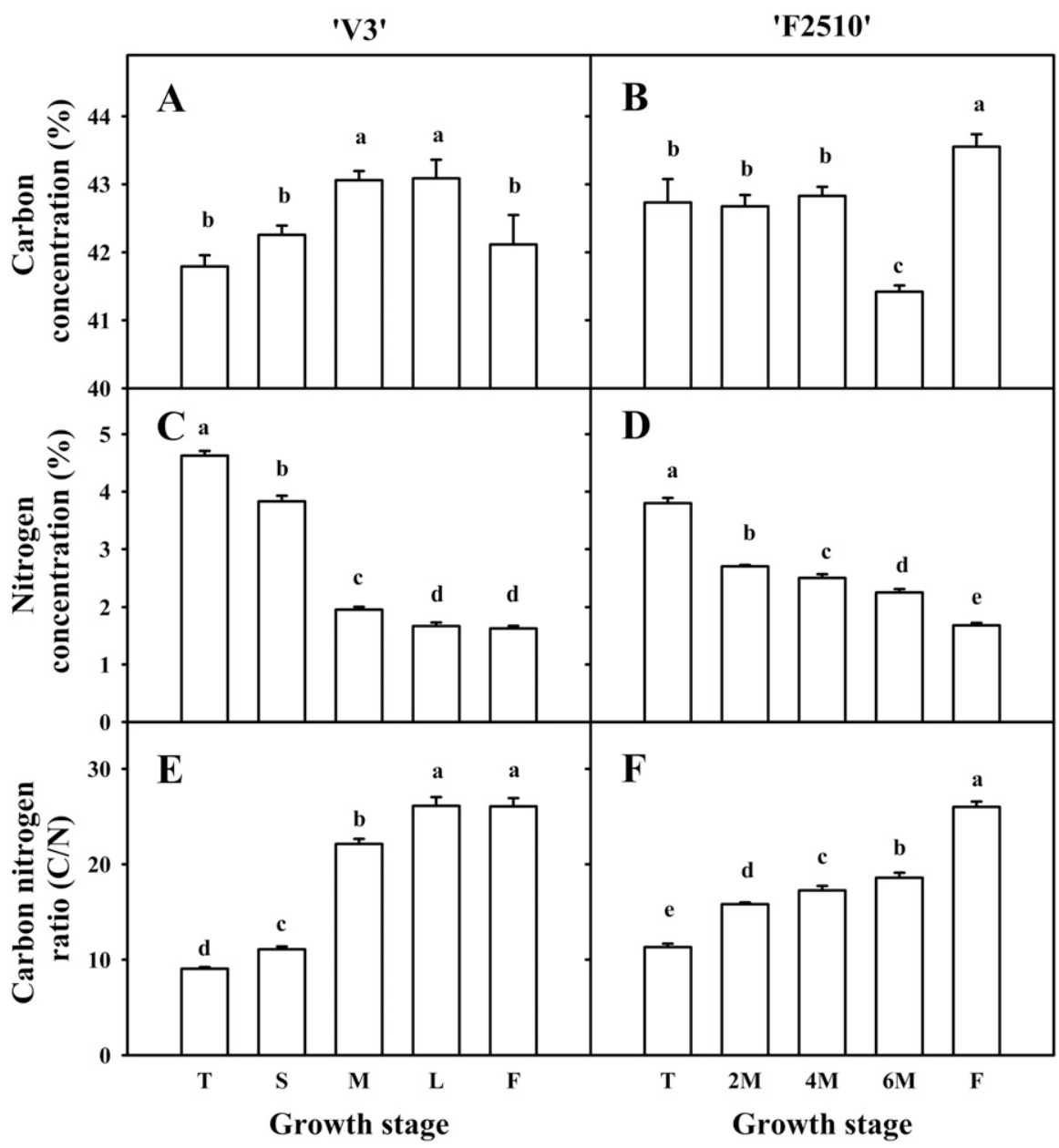

Fig. 2. Carbon (C) concentration, nitrogen $(\mathrm{N})$ concentration, and $\mathrm{C} / \mathrm{N}$ ratio in Phalaenopsis Sogo Yukidian 'V3' and Phalaenopsis Sogo Lotte 'F2510' at various growth stages. Stage T was tissueculture plantlet of 'V3' and 'F2510'. Stages S, M, and L represent vegetative growth stages of 'V3' in $4.5-, 8.5-$, and $10.5-\mathrm{cm}$ pots, respectively. Stages $2 \mathrm{M}, 4 \mathrm{M}$, and $6 \mathrm{M}$ were vegetative growth stages of 'F2510' after 2, 4, and 6 months out of flask, respectively. Stage F represents reproductive growth stage with half flowers opened in both cultivars. Samplings were done at the end of each stage. Different letters in the same panel were significantly different at $P \leq 0.05$ by the least significant difference test. Bars indicate SE; $n=10$.

Table 2. The effect of flowering on carbon $(\mathrm{C})$ and nitrogen $(\mathrm{N})$ concentrations and contents as well as $\mathrm{C} / \mathrm{N}$ ratio in Phalaenopsis Sogo Yukidian 'V3'at different plant parts.

\begin{tabular}{|c|c|c|c|c|c|}
\hline & $\begin{array}{l}\text { C concn } \\
(\% \mathrm{DW})\end{array}$ & $\begin{array}{l}\mathrm{N} \text { concn } \\
(\% \mathrm{DW})\end{array}$ & $\begin{array}{l}\mathrm{C} / \mathrm{N} \\
\text { ratio }\end{array}$ & $\begin{array}{c}\mathrm{C} \text { content } \\
(\mathrm{g})\end{array}$ & $\begin{array}{l}\mathrm{N} \text { content } \\
(\mathrm{mg})\end{array}$ \\
\hline \multicolumn{6}{|l|}{ Inflorescence } \\
\hline Half flowers open & 43.9 & 1.28 & 34.4 & 2.650 & 77.5 \\
\hline \multicolumn{6}{|l|}{ Shoot } \\
\hline $10.5-\mathrm{cm}$ pot & 43.6 & 1.64 & 26.7 & 2.86 & 108.1 \\
\hline Half flowers open & 41.8 & 1.70 & 24.7 & 4.09 & 166.2 \\
\hline Significance ${ }^{\mathrm{z}}$ & $*$ & NS & NS & $* * *$ & $* * *$ \\
\hline \multicolumn{6}{|l|}{ Roots } \\
\hline $10.5-\mathrm{cm}$ pot & 42.4 & 1.71 & 25.4 & 1.97 & 79.0 \\
\hline Half flowers open & 40.8 & 1.85 & 22.7 & 2.51 & 112.7 \\
\hline Significance & $*$ & NS & NS & $* * *$ & $* * *$ \\
\hline
\end{tabular}

\section{Discussion}

Sampling position for $C$ and $N$ analysis in phalaenopsis. $\mathrm{N}$ is an important mineral nutrient which can significantly affect growth and flowering of phalaenopsis. Appropriate $\mathrm{N}$ level in fertilizer is $100-200 \mathrm{mg} \cdot \mathrm{L}^{-1} \mathrm{~N}$ for phalaenopsis, which promotes vegetative
$\mathrm{N}$ fertilization $\left(300-400 \mathrm{mg} \cdot \mathrm{L}^{-1}\right)$ can result in reduced flower number (Lei, 2007; Wang, 2003). Symptoms of N deficiency include defoliation, considerable reduction of total leaf area, and chlorosis in phalaenopsis (Yoneda et al., 1997). The critical N concentration for $\mathrm{N}$ deficiency symptoms to become apparent was $0.6 \%$ to $0.9 \%$ in leaf of phalaenopsis (Yu, 2012).

Tissue analysis can directly reveal the nutrient status in plants, but sampling position must be considered. In the literature, $\mathrm{N}$ was found to be unevenly distributed in phalaenopsis, where upper leaves had higher N concentration (Poole and Sheehan, 1974; Susilo et al., 2013). Results from this research demonstrated that $\mathrm{N}$ concentrations of whole leaf in phalaenopsis were between $1.48 \%$ and $2.72 \%$ and upper leaves had higher $\mathrm{N}$ concentrations (Table 1). The new leaf is still expanding, which makes it hard to obtain uniform sampling and thus it is not suitable for sampling. Other research suggested the second mature leaf to be the appropriate part for tissue analysis (Mantovani et al., 2015). Results from this research indicated that the second to fifth mature leaves had relatively stable $\mathrm{N}$ concentration and thus are suitable leaves for tissue $\mathrm{N}$ analysis.

To minimize the injury to plants and to facilitate analysis work that follows, sampling a section of leaf instead of a whole leaf could be made if an appropriate leaf part is selected. $\mathrm{N}$ is not evenly distributed in a single leaf, thus sampling position on a leaf may affect the result of tissue analysis. In the second mature leaf, $\mathrm{N}$ concentration of Section 3 (middle part) was $1.96 \%$, which was very close to the whole leaf value $1.92 \%$ (Table 1). C concentration of Section 3 $(43.5 \%)$ was almost the same with that of the whole leaf (43.6\%). C/N ratio of Section 3 was 22.3, which was close to the whole-leaf value of 22.7 (Table 1). Kataoka et al. (2004) also indicated that middle part of the leaf is suitable for carbohydrate analysis in phalaenopsis. We conclude that the middle part of the second mature leaf is appropriate for tissue analysis to obtain representative $\mathrm{N}$ concentration in phalaenopsis.

Changes of tissue $C$ and $N$ composition in phalaenopsis during various developmental stages. Major developmental events like flushing, flowering, and fruiting often occurred with partitioning of $\mathrm{N}$ and $\mathrm{C}$ in plants. In different developmental stages, the distribution of $\mathrm{N}$ and $\mathrm{C}$ in tissue is also different (Malip and Masri, 2006; Suto et al., 1984; Tahir et al., 2003; Xia, 1993; Yong and Hew, 1995). In phalaenopsis ' $\mathrm{V} 3$ ', concentration of $\mathrm{N}$ decreased as plants became more mature (Susilo et al., 2014). In this study, we further examined the $\mathrm{C}$ and $\mathrm{N}$ changes from tissueculture plantlet stage to half flowers opened stage and compared the similarity and difference between two cultivars. The results confirmed that, in both phalaenopsis cultivars, tissue $\mathrm{N}$ concentration decreased with plant development (Fig. 2C and D). A high N concentration was detected in tissue-culture plantlet (4.6\% in 'V3'; $3.8 \%$ in 'F2510'). 
Table 3. The effect of flowering on carbon (C) and nitrogen (N) concentrations and contents as well as $\mathrm{C} / \mathrm{N}$ ratio in Phalaenopsis Sogo Lotte 'F2510' at different plant parts.

\begin{tabular}{|c|c|c|c|c|c|}
\hline & $\mathrm{C}$ concn $(\% \mathrm{DW})$ & $\mathrm{N}$ concn $(\% \mathrm{DW})$ & $\mathrm{C} / \mathrm{N}$ ratio & C content $(\mathrm{g})$ & $\mathrm{N}$ content $(\mathrm{mg})$ \\
\hline \multicolumn{6}{|l|}{ Inflorescence } \\
\hline \multicolumn{6}{|l|}{ Shoot } \\
\hline 6-month & 41.0 & 1.98 & 20.8 & 268.2 & 12.9 \\
\hline Significance $^{z}$ & $* * *$ & $* * *$ & $* * *$ & $* * *$ & $* *$ \\
\hline \multicolumn{6}{|l|}{ Roots } \\
\hline 6-month & 42.5 & 2.90 & 14.9 & 116.7 & 7.9 \\
\hline
\end{tabular}

$\overline{\mathrm{NS}}, * *, * * *$ represent nonsignificant or significant at $P \leq 0.01$ and 0.001 by $t$ test, respectively; $n=10$.

Table 4. Changes of dry weight (DW) and carbon (C) and nitrogen (N) concentrations and contents as well as C/N ratio in Phalaenopsis Sogo Lotte 'F2510' at various reproductive stages.

\begin{tabular}{|c|c|c|c|c|c|c|}
\hline Growth stage ${ }^{z}$ & Dry wt $(\mathrm{g})$ & C concn $(\% \mathrm{DW})$ & $\mathrm{N}$ concn $(\% \mathrm{DW})$ & $\mathrm{C} / \mathrm{N}$ ratio & C content $(\mathrm{mg})$ & $\mathrm{N}$ content $(\mathrm{mg})$ \\
\hline Stage 3 & $1.41 \mathrm{c}$ & $44.1 \mathrm{c}$ & $1.70 \mathrm{~b}$ & $25.9 \mathrm{~d}$ & $621.4 \mathrm{c}$ & $23.9 \mathrm{c}$ \\
\hline Stage 4 & $1.83 \mathrm{~b}$ & $44.9 \mathrm{~b}$ & $1.53 \mathrm{c}$ & $29.3 \mathrm{c}$ & $822.9 \mathrm{~b}$ & $28.1 \mathrm{ab}$ \\
\hline Stage 6 & $2.19 \mathrm{a}$ & $45.8 \mathrm{a}$ & $1.36 \mathrm{~d}$ & $33.8 \mathrm{a}$ & $1,001.0 \mathrm{a}$ & $29.5 \mathrm{a}$ \\
\hline Stage 7 & $2.13 \mathrm{a}$ & $45.8 \mathrm{a}$ & $1.39 \mathrm{~d}$ & $33.0 \mathrm{ab}$ & $974.6 \mathrm{a}$ & $29.5 \mathrm{a}$ \\
\hline Significance $^{x}$ & $* * *$ & $* * *$ & $* * *$ & $* * *$ & $* * *$ & $* * *$ \\
\hline
\end{tabular}

${ }^{\mathrm{z}}$ Seven-month-old plants were forced in a $25 / 20^{\circ} \mathrm{C}$ phytotron for 3 months and then transferred to a greenhouse with $27.0{ }^{\circ} \mathrm{C}$ average temperature. Stage $1: 0 \mathrm{~d}$ after forcing; Stage 2: $10 \mathrm{~d}$ after forcing; Stage 3: spiking; Stage 4: $40 \mathrm{~d}$ after spiking; Stage 5: bud visible; Stage 6: first flower opened; Stage 7: half flowers opened.

${ }^{\mathrm{y}}$ Means followed by different letters in columns are significantly different at $P \leq 0.05$ by the least significant difference test; $n=12$.

x*** represents significant at $P \leq 0.001$ by analysis of variance.

Table 5. Rate of dry weight, carbon (C), and nitrogen (N) gain in Phalaenopsis Sogo Lotte 'F2510' during various reproductive stages.

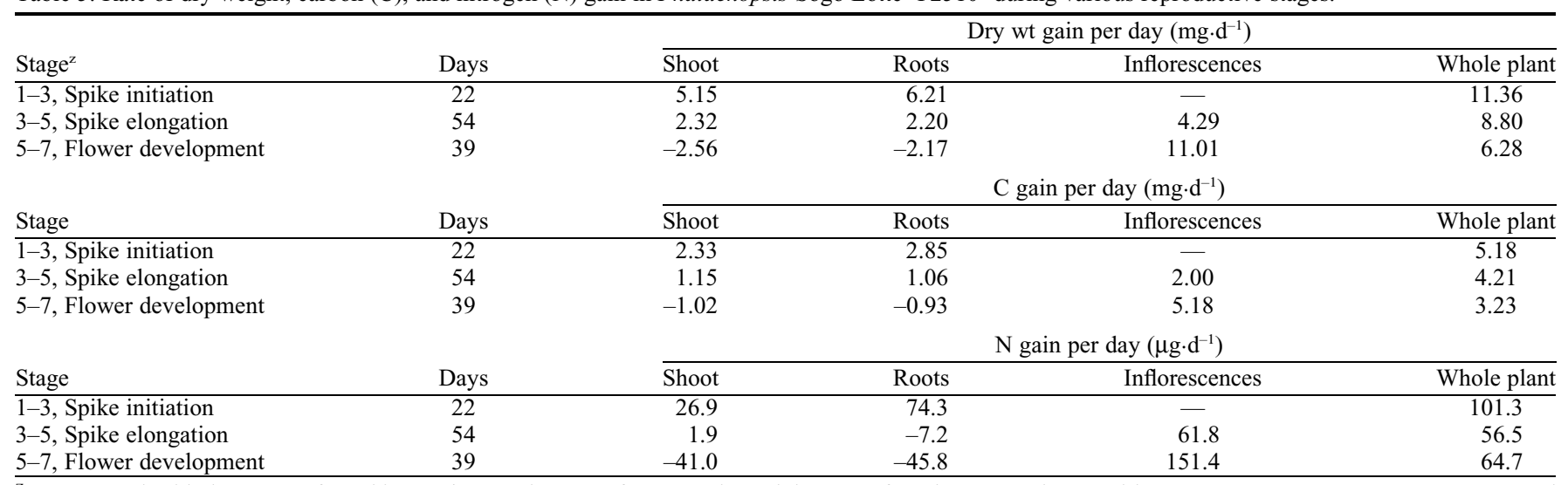

${ }^{\mathrm{z}}$ Seven-month-old plants were forced in a $25 / 20^{\circ} \mathrm{C}$ phytotron for 3 months and then transferred to a greenhouse with $27.0{ }^{\circ} \mathrm{C}$ average temperature. Stage $1: 0 \mathrm{~d}$ after forcing; Stage 2: $10 \mathrm{~d}$ after forcing; Stage 3: spiking; Stage 4: $40 \mathrm{~d}$ after spiking; Stage 5: bud visible; Stage 6: first flower opened; Stage 7: half flowers opened.

High tissue $\mathrm{N}$ concentration in tissue-culture plantlet was also reported in Phalaenopsis Sogo Yukidian 'V3' and Phalaenopsis amabilis, which might be caused by high $\mathrm{N}$ level (708 mg. $\mathrm{L}^{-1} ; 50.6 \mathrm{~mm} \mathrm{~N}$ ) in the tissue-culture medium (Chen, 2014).

$\mathrm{N}$ level in fertilizer significantly affects tissue $\mathrm{N}$ concentration in phalaenopsis (Poole and Seeley, 1978). Some growers deliberately decrease or even eliminate $\mathrm{N}$ supply before forcing to raise tissue $\mathrm{C} / \mathrm{N}$ ratio and to enhance flowering in phalaenopsis. In this research, $\mathrm{N}$ level in fertilizer during cultivation was maintained relatively stable at $50 \mathrm{mg} \cdot \mathrm{L}^{-1}$ in both cultivars. Results showed that $\mathrm{C} / \mathrm{N}$ ratio naturally increased as plants became more mature (Fig. 2E and F), without a deliberate decrease in $\mathrm{N}$ supplied, and those plants can be successfully forced without a decline in flowering quality. A further study is needed to quantify the effects of short-term $\mathrm{N}$ application on tissue $\mathrm{C}$ and $\mathrm{N}$ composition and flowering performance in phalaenopsis.

Flowering is the most important event in plant development. In Oncidium orchid, C/N ratio of back pseudobulbs decreased during flowering (Wang, 2011). Another research showed that concentrations of total nonstructural carbohydrate in the first back shoot and the second back shoot decreased during flowering in Oncidium (Hew and $\mathrm{Ng}$, 1996). Results from both studies mentioned previously indicated that stored nutrient might be mobilized to support the development of inflorescences. In Expt. 2, two cultivars had different trends in changes of
$\mathrm{N}$ concentration during reproductive growth (Tables 2 and 3). This may be due to different sizes of N pool. In large white-flowered 'V3', $\mathrm{N}$ content of mature plant in $10.5-\mathrm{cm}$ pot was $187 \mathrm{mg}$ (calculated from Table 2; i.e., $108+$ $79 \mathrm{mg}$ ); by contrast, 6-month-old small purple-flowered 'F2510' had only $20.8 \mathrm{mg}$ of $\mathrm{N}$ content (calculated from Table 3; i.e., $12.9+7.9 \mathrm{mg}$ ). With small-sized $\mathrm{N}$ pool, small-flowered 'F2510' at Stage 6M could not fully support the development of inflorescence $(13.0 \mathrm{mg} \mathrm{N})$ without a decrease in $\mathrm{N}$ concentration in shoot and roots (Table 3 ). By contrast, with a sufficient $\mathrm{N}$ pool, the large-flowered 'V3' had no significant changes in $\mathrm{N}$ concentration and $\mathrm{C} / \mathrm{N}$ ratio from mature-plant stage to half flowers open stage (Table 2). Lei (2007) used large, 
white-flowered phalaenopsis (Phalaenopsis amabilis) in $10.5-\mathrm{cm}$ pot as plant materials and found no significant changes in $\mathrm{N}$ concentration during reproductive stages, which might also be due to a sufficient $\mathrm{N}$ pool. In Expt. 3, N concentration decreased from $1.88 \%$ to $1.39 \%$, as growth stages of 7 month-old 'F2510' progressed from Stage 1 ( $0 \mathrm{~d}$ after forcing) to Stage 7 (half flowers opened; Table 4). This result was consistent with that of Expt. 2, where $\mathrm{N}$ concentration decreased during reproductive stage in small purple-flowered 'F2510' (Table 3).

Susilo et al. (2013) demonstrated that newly grown leaves and newly formed roots were major $\mathrm{N}$ sinks in vegetative growth stage, whereas stalks and flowers were major $\mathrm{N}$ sinks in the reproductive stage of phalaenopsis. In Expt. 3, major $\mathrm{N}$ sinks shifted from roots to inflorescences during forcing (Table 5). By using stable isotope ${ }^{15} \mathrm{~N}$ as a tracer, Susilo et al. (2014) determined that stored N contributed $43 \%$ of $\mathrm{N}$ in inflorescences at visible bud stage in large white-flowered 'V3'. In this research, we calculated the difference of $\mathrm{N}$ content between different stages in each organ, to determine the partitioning of $\mathrm{N}$ in various periods of growth. In spike initiation stage, ratio of newly gained $\mathrm{N}$ in shoot and roots was $26.6 \%$ and $73.4 \%$, respectively [i.e., 26.9:74.3 (calculated from Table 5)]. This observation suggested that root was the major sink organ during spike initiation stage. The inflorescence became a major $\mathrm{N}$ sink organ at spike elongation stage with the highest $\mathrm{N}$ gain rate of 61.8 $\mu \mathrm{g} \cdot \mathrm{d}^{-1}$ (Table 5), of which newly gained $\mathrm{N}$ (from fertilizer) contributed about $88.3 \%$ [i.e., (61.8-7.2)/61.8; calculated from Table 5] of total $\mathrm{N}$ gained in inflorescences. During flower development stage, shoot and roots had a negative $\mathrm{N}$ gain rate, indicating that these organs became $\mathrm{N}$ sources, which accounted for $27.1 \%$ (i.e., $41.0 / 151.4$; calculated from Table 5) and 30.3\% (i.e., 45.8/ 151.4) of total $\mathrm{N}$ gain in inflorescences, respectively. Total $\mathrm{N}$ gain in inflorescences in the three stages was $9.24 \mathrm{mg}$ [i.e., (61.8 $\left.\mu \mathrm{g} \cdot \mathrm{d}^{-1} * 54 \mathrm{~d}\right)+\left(151.4 \mu \mathrm{g} \cdot \mathrm{d}^{-1} * 39 \mathrm{~d}\right)$; calculated from Table 5], while total $\mathrm{N}$ loss in shoot and roots were $-1.50 \mathrm{mg}$ [i.e., (1.9 $\left.\left.\mu \mathrm{g} \cdot \mathrm{d}^{-1} * 54 \mathrm{~d}\right)+\left(-41.0 \mu \mathrm{g} \cdot \mathrm{d}^{-1} * 39 \mathrm{~d}\right)\right]$ and $-2.18 \mathrm{mg}$ [i.e., $\left(-7.2 \mu \mathrm{g} \cdot \mathrm{d}^{-1} * 54 \mathrm{~d}\right)+(-45.8$ $\left.\left.\mu \mathrm{g} \cdot \mathrm{d}^{-1} * 39 \mathrm{~d}\right) \mu \mathrm{g}\right]$, respectively. Stored N contributed $40 \%$ [i.e., $(1.50+2.18) / 9.24 \mathrm{mg}$ ] of $\mathrm{N}$ in inflorescences at half flowers opened stage (calculated from Table 5), which is very close to $43 \%$ found in a previous study (Susilo et al., 2014). Compared with leaves, roots stored more $\mathrm{N}\left(74.3\right.$ vs. $\left.26.9 \mu \mathrm{g} \cdot \mathrm{d}^{-1}\right)$ during spike initiation but translocated more $\mathrm{N}$ to inflorescences during spike elongation and flower development (Table 5). These results are consistent with previous findings, where roots of phalaenopsis ' $\mathrm{V} 3$ ' stored more $\mathrm{N}$ than leaves during mature plant stage and partitioned more $\mathrm{N}$ to inflorescences during reproductive stage (Susilo et al., 2014).

The potential for tissue $C$ and $N$ composition to be a maturity index in phalaenopsis. In juvenile stage, flowering cannot be induced even when the environment is appropriate for reproductive growth. As the plant grows and when forcing becomes possible, then a so-called mature stage is achieved. To ensure an accurate production plan, it is important for commercial growers to judge the maturity of phalaenopsis to determine the appropriate forcing schedule. In this research, although two phalaenopsis cultivars have huge difference in plant size, both cultivars had a decreasing trend in tissue $\mathrm{N}$ concentration (Fig. 2C and D). Data indicated that maturity was achieved at Stage M (10 months after deflasking) in the large, white-flowered 'V3' and Stage 6M (6 months after deflasking) in the small, purpleflowered 'F2510'. In these stages, both cultivars had similar $\mathrm{N}$ concentration values near $2 \%$. It is obvious that cultivars with short juvenile period had a faster rate of decrease in $\mathrm{N}$ concentration. In the small, purple-flowered 'F2510', N concentration decreased from $3.80 \%$ to $2.24 \%$, during 6 months after deflasking (Fig. 2D). But in the large, white-flowered ' $\mathrm{V} 3$ ', $\mathrm{N}$ concentration only decreased from $4.63 \%$ to $3.83 \%$, during 5 months after deflasking (Fig. 2C). This indicates that $\mathrm{N}$ concentration has the potential to become a maturity index. Future study is needed to construct a statistical prediction model.

In summary, $\mathrm{C}$ concentration in phalaenopsis had no obvious increasing or decreasing trend and neither did it have notable effects on $\mathrm{C} / \mathrm{N}$ ratio in this research. $\mathrm{N}$ concentration in leaves decreased as leaves became more aged (from top leaf to bottom leaf). The middle part of the second mature leaf is an appropriate sampling position for tissue analysis in phalaenopsis. We compared $\mathrm{C}$ and $\mathrm{N}$ composition in two phalaenopsis cultivars, 'V3' and 'F2510', which had a huge difference in morphology. $\mathrm{N}$ concentration decreased as growth stage progressed from tissue-culture plantlet to mature plant in both cultivars, and $\mathrm{C} / \mathrm{N}$ ratio consequently increased. $\mathrm{N}$ concentrations of plants at justmatured stages were around $2 \%$ in both cultivars, which indicates that $\mathrm{N}$ concentration is a potential maturity index in phalaenopsis. During reproductive growth stage, $\mathrm{N}$ concentration of small-flowered 'F2510' decreased, whereas that of large-flowered ' $\mathrm{V} 3$ ' had no significant change. This is attributed to the different size of N pool, where 'F2510' had smaller N pool size than 'V3'. Major N sink shifted from roots to inflorescences during forcing and flowering in ' $F 2510$ '. Newly absorbed $\mathrm{N}$ contributed $60 \%$ and stored $\mathrm{N}$ contributed $40 \%$ of total $\mathrm{N}$ to inflorescence development, indicating the importance of constant $\mathrm{N}$ supply during forcing. Results suggested that $\mathrm{C}$ and $\mathrm{N}$ are not evenly distributed in leaves and revealed the natural changes of $\mathrm{C}$ and $\mathrm{N}$ composition during various development stages. This research provides a better understanding of $\mathrm{C}$ and $\mathrm{N}$ partitioning in phalaenopsis, suggests a more precise sampling method, and offers information for a proper interpretation of tissue analysis results.

\section{Literature Cited}

Chen, W.S., L. Yang, W.H. Chen, H.Y. Liu, and Z.H. Liu. 1994. Gibberellin and temperature influence carbohydrate content and flowering in Phalaenopsis. Physiol. Plant. 90:391-395.

Chen, Y.J. 2014. Causes of lower leaf yellowing and symptoms of mineral nutrient deficiency in Phalaenopsis plantlets in vitro. Natl. Taiwan Univ., Taipei, Taiwan, MS Diss. (in Chinese with English abstract).

Hew, C. and C.K.Y. Ng. 1996. Changes in mineral and carbohydrate content in pseudobulbs of the C3 epiphytic orchid hybrid Oncidium Goldiana at different growth stages. Lindleyana 11:125134.

Kataoka, K., K. Sumitomo, T. Fudano, and K. Kawase. 2004. Changes in sugar content of Phalaenopsis leaves before floral transition. Sci. Hort. 102:121-132.

Klebs, G. 1918. Über die blütenbildung von Sempervivum. Flora oder Allgemeine Botanische Zeitung 111:128-151.

Lee, N. and C.M. Lin. 1984. Effect of temperature on growth and flowering of Phalaenopsis white hybrid. J. Chinese Soc. Hort. Sci. 30:223-231. (in Chinese with English abstract).

Lee, N. and C.M. Lin. 1987. Control the flowering of Phalaenopsis, p. 27-44. In: L.R. Chang (ed.). Proc. Symp. Forcing Cult. Hort. Crops. Special Publ. 10. Taichung District Agr. Improv. Sta., Changhua, Taiwan (in Chinese with English abstract).

Lee, N. and M.C. Wang. 1997. Changes in mineral composition and carbohydrate contents from juvenile to mature phase in white-flowered Phalaenopsis plants. J. Chinese Soc. Hort. Sci 43:295-305. (in Chinese with English abstract).

Lei, H.Y. 2007. Changes of mineral composition and fertilizer requirement of Phalaenopsis during reproductive stages. Natl. Taiwan Univ., Taipei, Taiwan, MS Diss. (in Chinese with English abstract).

Malip, M. and M. Masri. 2006. Establishment of protocol for carbohydrate analysis and monitoring seasonal variations between carbohydrates and nitrogen levels in Garcinia mangostana (mangosteen). Acta Hort. 727: 569-575.

Mantovani, C., R. de Mello Prado, and K.F.L. Pivetta. 2015. Foliar diagnosis in Phalaenopsis orchid plants subjected to application of nitrogen. Afr. J. Agr. Res. 10:4906-4912.

Ng, C.K.Y. and C.S. Hew. 2000. Orchid pseudobulbs-'false' bulbs with a genuine importance in orchid growth and survival! Sci. Hort. 83:165-172.

Poole, H. and J. Seeley. 1978. Nitrogen, potassium and magnesium nutrition of three orchid genera. J. Amer. Soc. Hort. Sci. 103:485-488.

Poole, H. and T. Sheehan. 1974. Chemical composition of plant parts of Phalaenopsis orchids. Amer. Orchid Soc. Bull. 43:242-246.

Royal Flora Holland. 2017. Top 10 house plants sold. 1 Oct. 2017. <http://annualreport.royalfloraholland. com/?_ga=2.37418217.871361800.1493781265 328736619.1493781263\#/feiten-en-cijfers/ kamerplanten?_k=26z8df>.

Sheehan, T. 1961. Effects of nutrition and potting media on growth and flowering of certain epiphytic orchids. Amer. Orchid Soc. Bull. 30:289-292.

Susilo, H. and Y.C.A. Chang. 2014. Nitrogen source for inflorescence development in $P$ halaenopsis: II. Effect of reduced fertilizer level on stored nitrogen use. J. Amer. Soc. Hort. Sci. 139:76-82.

Susilo, H., Y.C. Peng, and Y.C.A. Chang. 2014. Nitrogen source for inflorescence development 
in Phalaenopsis: I. Relative significance of stored and newly absorbed nitrogen. J. Amer. Soc. Hort. Sci. 139:69-75.

Susilo, H., Y.C. Peng, S.C. Lee, Y.C. Chen, and Y.C.A. Chang. 2013. The uptake and partitioning of nitrogen in Phalaenopsis Sogo Yukidian 'V3' as shown by ${ }^{15} \mathrm{~N}$ as a tracer. J. Amer. Soc. Hort. Sci. 138:229-237.

Suto, K., K. Tsutsui, and K. Sinoda. 1984. Effects of temperature and nitrogen nutrition on the growth and flowering in nobile-type Dendrobium. Bul. Veg. Ornamental Crops Res. Sta. 12:65-83.

Tahir, F., M. Ibrahim, and K. Hamid. 2003. Seasonal variation in nutrient concentration of bearing and non-bearing terminals in mango (Mangifera indica L.). Asian J. Plant Sci. 2:113-115.

Tanaka, T., T. Matsuno, M. Masuda, and K. Gomi. 1988. Effects of concentration of nutrient solution and potting media on growth and chemical composition of a Phalaenopsis hybrid. J. Jpn. Soc. Hort. Sci. 57:78-84. (in Japanese with English abstract).

U.S. Department of Agriculture. 2016. Floriculture crops 2015 summary. 3 Oct. 2017. <http://usda.
mannlib.cornell.edu/usda/current/FlorCrop/ FlorCrop-04-26-2016.pdf >.

Wada, K. and Y. Shinozaki. 1985. Flowering response in relation to $\mathrm{C}$ and $\mathrm{N}$ contents of Pharbitis nil plants cultured in nitrogen-poor media. Plant Cell Physiol. 26:525-535.

Wang, Y.C. 2011. Effect of carbon and nitrogen on development and flowering of Oncidium Gower Ramsey. Natl. Taiwan Univ., Taipei, Taiwan, MS Diss. (in Chinese with English abstract).

Wang, Y.T. 1995. Phalaenopsis orchid light requirement during the induction of spiking. HortScience 30:59-61.

Wang, Y.T. 2003. Effects of $\mathrm{N}$ and $\mathrm{P}$ concentration on growth and flowering of the Phalaenopsis orchid. HortScience 38:746-747.

Wang, Y.T. and L.L. Gregg. 1994. Medium and fertilizer affect the performance of Phalaenopsis orchids during two flowering cycles. HortScience 29:269-271.

Wang, Y.T. and E.A. Konow. 2002. Fertilizer source and medium composition affect vegetative growth and mineral nutrition of a hybrid moth orchid. J. Amer. Soc. Hort. Sci. 127:442-447.

Xia, M.Z. 1993. The relationship between sugarnitrogen ratio and reproductive organs abscission in faba bean (Vicia faba L.). J. Agron. Crop Sci. 170:348-353.

Yoneda, K., H. Momose, and S. Kubota. 1991. Effects of daylength and temperature on flowering in juvenile and adult Phalaenopsis plants. J. Jpn. Soc. Hort. Sci. 60:651-657. (in Japanese with English abstract).

Yoneda, K., H. Momose, and S. Kubota. 1992. Comparison of flowering behavior between mature and premature plants of Phalaenopsis under different temperature conditions. Jpn. J. Trop. Agr. 36:207-210. (in Japanese with English abstract).

Yoneda, K., M. Usui, and S. Kubota. 1997. Effect of nutrient deficiency on growth and flowering of Phalaenopsis. J. Jpn. Soc. Hort. Sci. 66:141147. (in Japanese with English abstract).

Yong, J.W.H. and C.S. Hew. 1995. Partitioning of ${ }^{14} \mathrm{C}$ assimilates between sources and sinks during different growth stages in the sympodial thin-leaved orchid Oncidium Goldiana. Intl. J. Plant Sci. 156:188-196.

Yu, Y.C. 2012. Growth response and gene expression profiling in Phalaenopsis under nitrogen, phosphorus, and potassium deficiency. Natl. Taiwan Univ., Taipei, Taiwan, MS Diss. 